\title{
ARTICLES
}

\section{What Is Left of the Radical Right?}

\section{The Economic Agenda of the Dutch Freedom Party 2006-2017}

\author{
Simon Otjes ${ }^{*}$
}

\begin{abstract}
This article examines the economic agenda of the Dutch Freedom Party. It finds that this party mixes left-wing and right-wing policy positions. This inconsistency can be understood through the group-based account of Ennser-Jedenastik (2016), which proposes that the welfare state agenda of radical right-wing populist parties can be understood in terms of populism, nativism and authoritarianism. Each of these elements is linked to a particular economic policy: economic nativism, which sees the economic interest of natives and foreigners as opposed; economic populism, which seeks to limit economic privileges for the elite; and economic authoritarianism, which sees the interests of deserving and undeserving poor as opposed. By using these different oppositions, radical right-wing populist parties can reconcile left-wing and right-wing positions.
\end{abstract}

Keywords: radical right-wing populist parties, economic policies, welfare chauvinism, populism, deserving poor.

\section{Introduction}

Political scientists find it difficult to pinpoint the economic policy position of radical right-wing populist parties. For instance, in the 2014 Chapel Hill Expert Survey (CHES), the uncertainty around the average economic left-right estimate of radical right-wing populist parties (expressed as the standard error) was $80 \%$ greater than the uncertainty for liberal or social-democratic parties (Bakker et al., 2014; author's calculations). Voters also find it difficult to place these parties. For instance, when asked to place the Dutch Freedom Party (Partij voor de Vrijheid, PVV) on a redistribution dimension, 14\% of voters in the 2012 Dutch electoral survey could not place it; $38 \%$ put them on the pro-redistribution side and $28 \%$ on the anti-redistribution side (Van der Kolk, Tillie, Van Erkel, \& van der Velden, 2012; author's calculations). ${ }^{1}$

\footnotetext{
* Assistant professor of political science at Leiden University and researcher at the Documentation
} Centre Dutch Political Parties of Groningen University. 
The lack of clarity that exists among experts and voters is reflected in debates among researchers who study radical right-wing populist parties. There are authors like Rovny (2013) who argue that, in general, radical right-wing populist parties mix left and right-wing policies to broaden their appeal. Other scholars such as Kitschelt and McGann (1995) position the family of radical right-wing populist parties on the economic right, whereas scholars such as De Lange (2007) place radical right-wing populist parties closer to the economic left.

This article is motivated by two questions. First, what position radical rightwing populist parties do take on the left-right dimension: is their policy position clearly left or right-wing, or are their positions mixed? Second, if their positions are mixed, the question is how radical right-wing populist parties can have views that seem inconsistent from the perspective of left-right politics but still are internally coherent. So the goal of the article is not to explain ('erklären') why radical right-wing populist parties have a particular position on the left-right dimension but to understand ('verstehen') how they can have a set of positions that appear to be contradictory from the perspective of left-right politics. The group-based account of Ennser-Jedenastik (2016) will be an important theoretical device to this end. He argues that the core elements of their ideology, their populism, nativism and authoritarianism, informs their economic profiles. Each of these elements is linked to a specific economic agenda: economic authoritarianism is a combination of limiting welfare state access to undeserving citizens, whose poverty is seen as a result of their moral failing, and expanding welfare state access for deserving citizens, whose poverty is thought to be beyond their control; economic nativism is reflected in welfare chauvinism and economic protectionism; and economic populism is understood here as the opposition to the economic privileges of elite groups, who disregard the interests of the people they are supposed to serve.

As will be shown here, this account allows radical right-wing populists to mix left and right-wing positions as they combine policies that benefit or penalize different groups. Because radical right-wing populist parties are economically populist, they are against the privileges of both bankers (a left-wing proposal) and bureaucrats (a right-wing proposal). Because they are economically nativist and authoritarian, they want to roll back the welfare state for immigrants and undeserving poor (right-wing) and extend it for natives and deserving poor (left-wing).

In addition to the theoretical integration of thinking in terms of left and right and in terms of nativism, authoritarianism and populism, this article extends the group-based account in three ways: by looking at more issues, another party and the parliamentary arena. The group-based account of EnnserJedenastik (2016) was developed to understand the welfare state policy of radical right-wing populist parties. This article applies it to economic policy in a broad perspective, namely as all ways in which the government can intervene or abstain from intervening in the economy. This selection does not just include welfare state issues, but also proposals that concern other spheres such as taxation, business regulation and housing for as far as they have implications for, for example, economic growth, economic equality and the budget. Moreover, this article looks at a different case, the Dutch Freedom Party, where Ennser-Jedenastik's article ana- 
lysed the Austrian Freedom Party (Freiheitliche Partei Österreichs, FPÖ). Finally, this article analyses parliamentary behaviour, specifically parliamentary resolutions introduced by PVV MPs. This offers a greater wealth of data and shows that economic authoritarianism, populism and nativism are more than campaign tools.

Since the famous statement of Mudde (2007, p. 119), namely that it is not the economy, stupid', much has changed. Understanding the economic profiles of radical right-wing populist parties is of great value, as Mudde (2016, p. 11) acknowledged almost a decade later: the study of radical right-wing populism 'must move beyond the dominant focus on the two issues of immigration and European integration, and reflect the broader range of [...] socio-economic issues'. There are a number of reasons for this: First, many radical right-wing populist parties have undergone a process of mainstreaming; this process includes attaching greater importance to economic issues (Akkerman, De Lange, \& Rooduijn, 2016; Lefkofridi \& Michel, 2017) Second, radical right-wing populist parties have come closer to government power, either as government parties or support parties of minority cabinets. This means that these parties actually have the chance to influence government policy, a large share of which concerns economic management. For instance, recent evidence suggests that radical right-wing populist parties have been able to get welfare chauvinist policies implemented, as Jørgensen and Thomsen (2016) illustrate in their study of the limits of social welfare programmes for immigrants and refugees in Denmark. At the same time, government participation can create new dilemmas for these parties such as when their natural allies are on the political right but their voters have left-wing economic preferences (Afonso, 2015).

This article first charts the literature on the economic position of radical right-wing populist parties. Next, it introduces the case of the PVV, considers what the selection of this case means in terms of external validity and discusses the study's methodology. Next, it shows how radical right-wing populist parties can balance left-wing and right-wing positions. The conclusion in turn focuses on the meaning of these results for the general discussion of the economics of radical right-wing populism.

\section{Radical Right-Wing Populism Between Economic Right and Left}

Until the end of the twentieth century, many political scientists agreed that parties of the populist radical right also pursued a right-wing, free market economic agenda. (Betz, 1994; Ignazi, 1992; Kriesi et al., 2008). Kitschelt and McGann (1995) even went so far as to term the combination of authoritarian, repressive, nationalist positions on cultural matters and pro-market positions on economic matters a 'winning formula' for the radical right. In their view, the combination of economic and cultural policies explained much of the electoral success that these parties had in the 1980s and early 1990s.

Against this consensus, Mudde (2007, p. 119) took a clear position: 'it's not the economy stupid'. He showed that actually many radical right-wing populist 
parties did not favour neo-liberal economic ideas. Moreover, he argued that their economic policy positions did not motivate voters to vote for radical right-wing populist parties. Mudde (2007, p. 122) suggested that the economic agendas of radical right-wing populist parties did share nativism, a core feature of the ideology of the populist radical right: many of these parties had protectionist positions on trade and welfare chauvinist positions regarding the access of immigrants to social services. On the subject of more or less state intervention these parties took centrist or mixed positions (Mudde, 2007, pp. 136-137).

Subsequent studies have looked into this perceived centrism. De Lange (2007) suggested that the combination of such centrist economic views in combination with the parties' continued commitment to law-and-order and anti-immigration policies forms a 'new winning formula', as this combination allows radical right populist parties to appeal to working class voters. Lefkofridi and Michel (2017), Kriesi et al. (2012), Eger and Valdez (2015), Ivaldi (2015) and Harteveld (2016) observe a further shift to the left on economic issues in many cases that they study. Their research suggests that many radical right-wing populist parties now combine left-wing positions on economic issues with right-wing positions on cultural issues. This combination of left-wing and authoritarian positions is where according to Van der Brug and Van Spanje (2009) most European voters are concentrated but no parties place themselves: a new winning formula. This implies that economic policies are only tactical tools for radical right-wing populist parties 'to be abandoned as soon as the political wind changed' (Minkenberg, 2000, pp. 173-174).

Other academics, however, argue that the inconsistent positions that radical right-wing populist parties had on economic issues meant that these parties are neither left nor right: Derks (2006), for instance, argues that radical right-wing populist voters and parties desire a more equal distribution of income but at the same time do not believe that the welfare state can realize this in an efficient way; that is these voters favour the principle of egalitarianism but not the principle of economic interventionism, both of which are considered to be the same from the traditional left-right perspective. Rovny (2013, pp. 5-6) also observes inconsistency in the left-right position of radical right-wing populist parties. He attributes this to a conscious strategy by these parties to capture as many voters as possible by taking vague and ambiguous policy positions.

These ideas are tested here for the Freedom Party on the basis of the following three mutually exclusive expectations:

Left-wing expectation: A radical right-wing populist party consistently takes left-wing policy positions on social-economic matters.

Right-wing expectation: A radical right-wing populist party consistently takes right-wing policy positions on social-economic matters.

Mixed expectation: A radical right-wing populist party takes both left-wing and right-wing policy positions on social-economic matters. 


\section{The Group-Based Approach of the Economic Agenda of Radical Right- Wing Populists}

In contrast to the existing literature, which focuses on the left-right position of radical right-wing populist parties, Ennser-Jedenastik (2016) has offered the group-based account to understand their economic policies. These reflect their radical right-wing populist ideology and specifically its key elements: populism, nativism and authoritarianism. Each of these three elements has economic implications.

Nativism is an ideology that holds that the state should be inhabited exclusively by members of the native group (Mudde, 2007, p. 19). It sees non-native, 'alien' elements as threatening to the homogeneity of the nation state. It creates a dichotomy between 'us' and 'them'. Mudde (2007) suggests that nativism can feed into the economic policies of radical right-wing populist parties. This can affect their views on immigration and trade. When analysing the welfare state agenda of the FPÖ, Ennser-Jedenastik (2016, p. 412) saw the implication of its anti-immigration position: 'Full benefits should be extended only to members of the native group, while non-natives should receive limited support if any.' This position is generally known as welfare state chauvinism (Andersen \& Bjørklund, 1990 , p. 212). The core idea is that in order to maintain solidarity within the welfare state, the welfare state should be restricted only to native people, and foreigners should be excluded (De Koster, Achterberg, \& van der Waal, 2012; Keskinen, 2016). Many authors observe this kind of policy in the economic agendas of radical right-wing populists (De Koster et al., 2012; Keskinen, 2016; Lefkofridi \& Michel, 2017; Mudde, 2007; Norocel, 2016; Schumacher \& Van Kersbergen, 2016). Yet if we go beyond welfare state issues and look at a broader array of economic issues, we can see a second way in which nativism may inform a party's economic policies: opposition to trade, which may threaten blue-collar jobs (Van der Waal \& de Koster, 2017). Radical right-wing populist parties may favour protectionist policies such as tariffs against international trade in order to protect native jobs. Economic nativism takes a zero-sum approach to international economics: if a country trades with another country, only one can benefit. From the same perspective, economic nativism opposes development aid and bailouts of Eurozone countries: if a country sends aid to another country, this represents a loss of resources for the country that gives aid.

The idea of economic nativism can help to understand the conditions under which radical right-wing populist parties advocate right-wing economic policies:

Non-native expectation: A radical right-wing populist party takes right-wing policy positions on social-economic matters if the policy affects non-native groups.

Populism is a thin ideology. It consists of three claims (Mudde, 2007): first the people are virtuous and homogeneous. Second, there is the elite, which is corrupt and acts as a bloc. The elite have deprived the people of their ability to rule. Third, the populists seek to remedy this: according to populism, the will of the people 
should become policy. Populism is a thin ideology because the terms of people and elite are empty vessels that can be imbued with meaning derived from different ideologies (Stanley, 2008), such as neo-liberalism or socialism (March, 2011; Pauwels, 2010). This would mean that there is no such thing as populist economics. Ennser-Jedenastik (2016, p. 414), however, argues that populists will tend to strip politicians and bureaucrats of any economic privilege and that taxpayer money should be used to the advantage of the 'common man'. Economic policies that seek to restrain the economic role of elite groups, by reducing the size of the bureaucracy, the power of management in the public sector and the spending for the salaries of politicians are economic populist in this sense. These policies are often motivated by the idea that in the public sector these elite groups pursue their own self-interest too much and neglect the interest of the groups their institutions are supposed to serve: citizens, students and patients, teachers and doctors. Ennser-Jedenastik (2016) looks only at public sector elites, but his logic can be transferred to private sector elites as well, such as bankers: here, populists argue that the elite's focus on their own self-interest has endangered the savings of normal people and that therefore their freedom and income should be capped in. Economic populism is different from both the economic left and the economic right. Where the economic left would tend to turn against the privileges of private sector elites (e.g. bankers), the economic right would turn against the privileges of public sector elites (e.g. civil servants). Populism takes aim at both owing to its anti-elitism.

Economic populism can help to understand the conditions under which radical right-wing populist parties pursue left-wing or right-wing economic policies:

Public elites expectation: A radical right-wing populist party takes right-wing policy positions on social-economic matters if the policy affects public-sector elite groups.

Private elite expectation: A radical right-wing populist party takes leftwing policy positions on social-economic matters if the policy affects privatesector elite groups.

Authoritarianism is the idea that 'infringements on authority are to be punished severely' (Mudde, 2007, p. 413). It makes a distinction between, on the one hand, criminal, immoral groups that ought to be punished and, on the other hand, innocent, moral groups that ought to be protected. This article follows the work of Ennser-Jedenastik (2016, p. 413) and Afonso and Papadopolous (2015, p. 620), who explicitly link authoritarianism to the distinction between deserving and undeserving poor. There are the undeserving poor, whose poverty can be attributed to their own moral failing and who exploit and cheat the welfare state. Opposed to them are the deserving poor, disabled people whose poverty is due to circumstances beyond their control and pensioners who have built up their countries after the Second World War. To ensure the solidarity in the welfare state, the undeserving groups must be excluded from its benefits. We can see the logic of authoritarianism return here: there are immoral, criminal groups who ought to be punished, those who can work but still rely on the welfare state. Their parasit- 
ism undermines the social order necessary to maintain the welfare state. From the perspective of authoritarianism, the deserving poor are a moral, innocent group, which ought to be protected. The notion of 'deservingness' plays an important role in the sociological literature on welfare state support (Handler, 2004; Van Oorschot, 2006; Will, 1993). Indeed, citizens tend to view seniors and disabled people as deserving of government support (Bang Petersen, Sloothuus, Stubager, \& Togeby, 2010; Van Oorschot, 2006). People who commit social fraud have lost their entitlement to support and tend to be seen as the least deserving by citizens. Economic authoritarianism applies to any proposal that seeks to limit access to public services for some group, characterized as undeserving, or seeks to expand public services for some other groups, identified as being deserving. An example would be a proposal to expel remorseless bullies in order to protect innocent school children. ${ }^{2}$

This distinction between deserving and undeserving groups that is at the core of economic authoritarianism may be useful to differentiate left-wing and rightwing economic policies of radical right-wing populist parties:

Deserving groups expectation: A radical right-wing populist party takes rightwing policy positions on social-economic matters if the policy affects undeserving groups.

Undeserving groups expectation: A radical right-wing populist party takes left-wing policy positions on social-economic matters if the policy affects deserving groups.

\section{Case Selection}

It is the goal of the article to understand how radical right-wing populist parties can balance left and right-wing policies because of their economic nativism, populism and authoritarianism. To this end we select the PVV. The PVV is a most likely case to observe both a mix of left and right-wing positions. As can be seen in Table 1, in its short existence it made the strongest shift from right to left of all radical right-wing populist parties in Western Europe: between 2006 and 2014 , according to the CHES, it shifted from 8.3 to 4.6 on a zero to ten socialeconomic left-right scale. This is the largest shift a radical right-wing populist party has made in the database. The PVV shifted from among the rightmost quartile among the radical right-wing populists to the leftmost quartile. So it is likely that this party has pursued both left-wing and right-wing policies. As shown in Table 2, the economic policy positions of other political parties in the Netherlands remained relatively stable during this period. As a most likely case to observe this phenomenon, the extent to which one can generalize from this case is limited. The issue of generalization will be discussed in the conclusion.

The PVV is often characterized as a radical right-wing populist party for its combination of nativism, populism and authoritarianism (Akkerman et al., 2016; De Lange \& Art, 2011; Mudde, 2013; Otjes \& Louwerse, 2015; Pellikaan, de Lange 
Table 1 CHES Social-Economic Left-Right Estimates for Radical Right-wing Populist Parties

\begin{tabular}{|c|c|c|c|c|c|c|c|c|}
\hline Country & English Name & $\begin{array}{l}\text { National Lan- } \\
\text { guage }\end{array}$ & 1999 & 2002 & 2006 & 2010 & 2014 & $\begin{array}{l}\text { Chan } \\
\text { ge }\end{array}$ \\
\hline Finland & Finns Party & Perussuomalaiset & 5.40 & - & 4.82 & 4.30 & 4.11 & -1.29 \\
\hline Denmark & $\begin{array}{l}\text { Danish People's } \\
\text { Party }\end{array}$ & Dansk Folkeparti & 7.29 & 6.08 & 4.75 & 5.45 & 4.50 & -2.78 \\
\hline Netherlands & Freedom Party & Partij voor de Vrijheid & - & - & 8.29 & 5.23 & 4.55 & -3.73 \\
\hline Sweden & $\begin{array}{l}\text { Sweden Demo- } \\
\text { crats }\end{array}$ & Sverigedemokraterna & - & - & - & 5.55 & 5.40 & -0.15 \\
\hline Austria & $\begin{array}{l}\text { Austrian Freedom } \\
\text { Party }\end{array}$ & $\begin{array}{l}\text { Freiheitliche Partei } \\
\text { Österreichs }\end{array}$ & 6.40 & 7.31 & 4.83 & 5.00 & 5.50 & -0.9 \\
\hline Belgium & Flemish Interest & Vlaams Belang & 8.76 & 7.90 & 7.13 & 7.93 & 5.50 & -3.26 \\
\hline France & National Front & Front National & 8.71 & 6.00 & 6.63 & 6.50 & 5.91 & -2.81 \\
\hline Italy & Northern League & Lega Nord & 8.83 & 7.28 & 8.14 & 7.33 & 7.29 & -1.55 \\
\hline Norway & Progress Party & Fremskrittspartiet & - & - & - & - & 7.50 & - \\
\hline Switzerland & $\begin{array}{l}\text { Swiss People's } \\
\text { Party }\end{array}$ & $\begin{array}{l}\text { Schweizerische Volk- } \\
\text { spartei }\end{array}$ & - & - & - & - & 7.50 & - \\
\hline Germany & $\begin{array}{l}\text { Alternative For } \\
\text { Germany }\end{array}$ & $\begin{array}{l}\text { Alternative für } \\
\text { Deutschland }\end{array}$ & - & - & - & - & 8.33 & - \\
\hline $\begin{array}{l}\text { United } \\
\text { Kingdom }\end{array}$ & \multirow{2}{*}{\multicolumn{2}{|c|}{ United Kingdom Independence Party }} & 7.81 & - & 8.38 & 8.17 & 8.57 & +0.76 \\
\hline Average & & & 7.60 & 6.91 & 6.62 & 6.16 & 6.22 & -1.38 \\
\hline
\end{tabular}

Source: Bakker et al. (20/4).

\& van der Meer, 2016; Vossen, 2013). The extensive analysis of Vossen (2013, pp. 65-110) characterizes its ideology as based on these pillars. One can illustrate with quotes from their election manifesto: statements like 'Islam does not belong to the Netherlands' or 'Mass immigration is very harmful for the Netherlands' exemplify the party's nativism (PVV, 2012, p. 35); the call for tough penalties for those who break the law show the party's authoritarianism (PVV, 2012, pp. 30-31); and statements like 'The progressive elite are terrified of the voice of the people. We are not. So let's open the voting booth and let the Dutch people speak' (PVV, 2012, p. 27) illustrate the party's populism.

The PVV emerged from the Dutch Liberal Party (Volkspartij voor Vrijheid en Democratie, VVD). The Liberal Party, as Table 2 shows, has a right-wing economic agenda. It focuses on market solutions, lowering taxation and shrinking government. The party was formed in 2004, when Geert Wilders quit the parliamentary party of the Liberal Party after a conflict over the ten-point plan that he had written: he advocated that the party move to the right on cultural and economic matters (Wilders \& Oplaat, 2004). Between 2004 and 2006 Wilders operated as an independent MP. During this period the Liberal Party governed in a centre-right coalition with the Christian Democratic Appeal (Christen-Democratisch Appèl, 
Table 2 CHES Social-Economic Left-Right Estimates for Dutch Political Parties

\begin{tabular}{|c|c|c|c|c|c|}
\hline English Name & National Language & 2006 & 2010 & 2014 & Change \\
\hline Socialist Party & Socialistische Partij & 1.11 & 1.50 & 1.00 & -0.11 \\
\hline Party for the Animals & Partij voor de Dieren & - & 3.55 & 2.43 & -1.2 \\
\hline GreenLeft & GroenLinks & 2.00 & 3.00 & 2.67 & +0.67 \\
\hline Labour Party & Partij van de Arbeid & 3.56 & 3.57 & 3.22 & -0.34 \\
\hline 50Plus & & - & - & 3.67 & - \\
\hline ChristianUnion & ChristenUnie & 4.13 & 5.00 & 4.11 & -0.02 \\
\hline Freedom Party & Partij voor de Vrijheid & 8.29 & 5.23 & 4.55 & -3.73 \\
\hline Democrats 66 & Democraten 66 & 5.22 & 5.50 & 6.56 & +1.33 \\
\hline $\begin{array}{l}\text { Christian-Democratic } \\
\text { Appeal }\end{array}$ & Christen-Democratisch Appèl & 5.56 & 6.50 & 6.56 & +1.01 \\
\hline Political Reformed Party & $\begin{array}{l}\text { Staatkundig Gereformeerde } \\
\text { Partij }\end{array}$ & - & 6.50 & 6.89 & +0.39 \\
\hline Liberal Party & $\begin{array}{l}\text { Volkspartij voor Vrijheid en } \\
\text { Democratie }\end{array}$ & 7.89 & 8.29 & 8.33 & +0.44 \\
\hline Average & & 4.72 & 4.86 & 4.54 & -0.18 \\
\hline
\end{tabular}

Source: Bakker et al. (20/4).

CDA) and social-liberal Democrats 66 (Democraten 66, D66). Both parties embraced a moderate version of the Liberal Party agenda and cooperated with market-based reforms of healthcare and cutbacks on pensions. In 2006 the PVV entered in the parliamentary election and won nine seats out of 150. After this election, a centre-left coalition was formed by the Christian-Democrats, the social-democratic Labour Party and the Christian-Social Union in Germany (ChristenUnie, CU). This cabinet was committed to the renewal of the welfare state. After the financial crisis of 2008, however, it was forced to balance its short-term investments with long-term austerity measures in order to meet European budgetary requirements. After the 2010 elections, the PVV became a support party for a centre-right coalition of CDA and VVD. The cabinet followed the austerity agenda of the previous cabinet. The support agreement committed the PVV to the budgetary policies of the cabinet but specifically excluded the pension age and European economic cooperation. The PVV's cooperation with the centre-right cabinet lasted until 2012, when the PVV backed out of negotiations over budget cuts. After the 2012 elections, a centrist Liberal-Labour coalition came to power, which the PVV strongly opposed.

\section{Methodology}

Most of the studies of the economic policy positions of radical right-wing populist parties have focused on their election manifestos or on expert placement (Akkerman et al., 2016; De Lange, 2007; Eger \& Valdez, 2015; Ennser-Jedenastik, 2016; Lefkofridi \& Michel, 2017; Rovny, 2013; Schumacher \& Van Kersbergen, 2016). 
Election manifestos have a few important drawbacks for those who want to study economic policy agendas, however: in manifestos, parties can afford to be vague. Moreover, as radical right-wing populist parties tend to keep these documents short and focus on issues like safety and immigration, the economic policy paragraphs can be relatively short. Two of the four PVV manifestos were shorter than ten pages. Expert surveys, in contrast, have the problem that one can study only what the scholarly community already expects to be present at the time of the survey. It is difficult to test the extent to which new concepts such as 'economic populism' or 'economic nativism' matter in previous periods if questions about this were not included in pre-existing surveys. Therefore, this study focuses on parties' activity in parliament. ${ }^{3}$ In parliament, parties produce a host of proposals that allow for a more extensive empirical basis. Specifically, this analysis will look at the substantial proposals PVV members make in the form of motions. After any committee or plenary debate an MP can propose a motion. ${ }^{4} \mathrm{~A}$ motion is an oft-used parliamentary tool that allows a party to get a parliamentary majority to back a judgment or a wish (Bovend'Eert \& Kummeling, 2010, p. 342; Visscher, 1994 , p. 98). Both opposition and coalition parties use this tool, although opposition MPs use it more often (Louwerse \& Otjes, 2016). Except for motions of noconfidence, cabinets need not implement motions. Still they play an important role in the policymaking process: ministers often refer to adopted motions when they propose legislation (Visscher, 1994, pp. 118-120). This article examines motions proposed by the PVV in the lower house of the Dutch Parliament concerning economic policies. The individual unit of measurement is the motion. Motions can be aggregated for different periods or categories. This study examines all motions proposed between 2006 and 2017, which can be accessed through Louwerse, Otjes, and Van Vonno (2017). The motions where a PVV MP was the first sponsor were selected. ${ }^{5}$ Multiple MPs can sponsor motions, but the first sponsor tends to be the author of the text. There are practically no restrictions to introducing a motion by a single MP except that it must pertain to an issue that is discussed in parliament. A large number of motions on economic issues are introduced in the yearly budget debates when any issue concerning the policy of a government department can be debated. Here, those motions were selected that were classified under the labels 'work', 'finance', 'the economy', 'education', 'health', 'housing' and 'social security' by the clerk of the lower house. This includes all motions that were proposed during yearly budgetary discussions. Motions that concern agriculture, defence, justice and transport were excluded. ${ }^{6}$ 


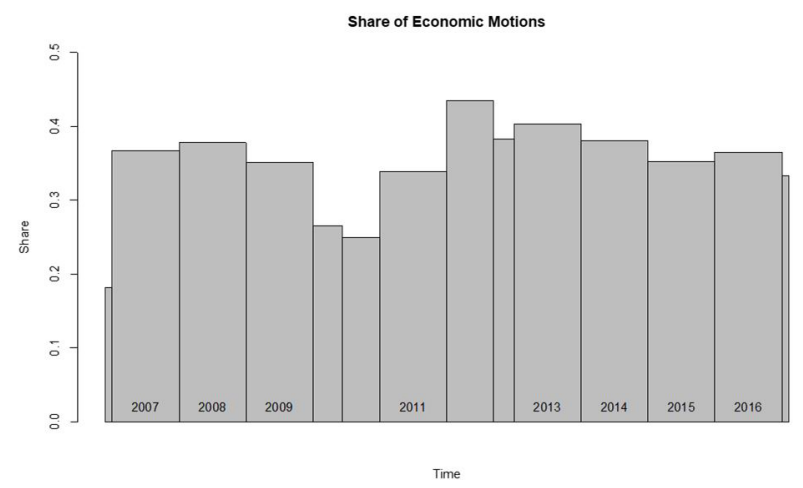

Figure 1 Share of Economic Motions

Share of all PVV motions that concern economic issues over time. The bars are years, unless there have been elections, in which case the years are split in before and after the election periods.

Out of a total of 2646 PVV motions, 973 were economic in nature (37\% of all its motions). This is a considerable share of the party's activities. The introduction of this article defined economic issues as all ways in which the government can intervene or abstain from intervening in the economy. A motion was deemed economic if it obliged the government to spend or tax either more or less, if it obliged the government to decrease or increase regulation in economic sectors or if it changed access to social services, education, healthcare or social housing. All coding was done by the author. Figure 1 shows that as a share of total activity of the party, economic issues stay roughly equal, around a third of all proposals.

The key question is whether radical right-wing populist parties consistently take policy positions that go in a left- or right-wing direction or whether their position is mixed. The economic left and right motions are defined in the following way: economic left-wing motions seek to:

1 increase the government's role in the economy by nationalizing sectors;

2 increase the government's role in the economy by increasing taxation;

3 increase the government's role in the economy by increasing regulation;

4 increase the government's role in the economy by increasing government spending;

5 increase economic equality through redistribution of income;

6 or increase economic equality by favouring the interests of weaker parties (such as employees, patients, consumers, pensioners, tenants) over stronger ones (such as businesses or home-owners).

Economic right-wing motions seek to

1 decrease the government's role in the economy by privatizing sectors;

2 decrease the government's role in the economy by reducing taxation; 
3 decrease the government's role in the economy by reducing regulation;

4 decrease the government's role in the economy by reducing government spending;

5 decrease economic equality by limiting access to social services;

6 or decrease economic equality by favouring the interests of stronger parties (such as businesses or home-owners) over weaker ones.

A separate category was made for motions that were neither left- nor right-wing. This includes motions that

1 raise as much revenue as they cost (for instance, proposing a spending increase in healthcare and an equivalent cut to subsidies for the arts);

2 are aimed at providing or cutting public services to small specific groups, without specifying that this would lead to more or less spending overall;

3 concern international economic issues (e.g. Eurozone membership);

4 pursue valence goals such as growth, stability or fighting fraud;

5 or concern the organization of specific (semi-)public agencies.

After all economic motions are coded as either left, right or neutral, they are coded as economic populist, authoritarian or nativist. These are approached as frames. This is not because these three are seen here as merely a rhetorical style (as Jagers and Walgrave (2007) have argued about populism), but because this ideology expresses itself as frames in written documents. They are the observable expressions of these ideologies in these texts. These frames are present when an opposition is drawn between two groups. As discussed previously, each of the frames draws upon some opposition: between the people and the elite in populism; between national groups and foreigners in nativism; between the deserving and the undeserving poor in authoritarianism. A frame is present when motions explicitly mention at least one of the two groups or use language that implicitly refers to these groups. If one would rely only on explicit mentions of these groups, motions in which the groups are reified or mentioned indirectly would be excluded, such as motions that refer to managers as 'overhead'. This categorization is not exclusive: a motion can be right-wing, economically nativist and economically populist at the same time. Table 3 provides examples of groups.

To test the expectations whether the PVV's economic policy positions are consistently left-wing, right-wing or mixed, the balance between left-wing and right-wing statements is used. This is the share of left-wing motions in a year subtracted from the share of right-wing motions. If all motions are right-wing the value is one; if all motions are left-wing the value is minus one. The value is zero if there is a perfect balance between left-wing and right-wing motions or if all motions are neutral. The left-wing expectation is corroborated if this score is clearly and consistently positive; the right-wing expectation is corroborated if this score is clearly and consistently negative; the mixed expectation if this score is close to zero. The idea is that economic nativism, authoritarianism and populism can be used to understand the choice for left or right-wing policies. To test the expectations concerning the conditions under which the PVV pursues left- or 
Table 3 Referents of Economic Populism, Nativism and Authoritarianism

\begin{tabular}{|c|c|c|c|c|}
\hline Aspect & Referent I & & Referent 2 & \\
\hline $\begin{array}{l}\text { Economic Popu- } \\
\text { lism }\end{array}$ & Elite & $\begin{array}{l}\text { Civil Servants } \\
\text { Directors of } \\
\text { schools } \\
\text { Directors of hos- } \\
\text { pitals } \\
\text { Directors of pub- } \\
\text { lic housing com- } \\
\text { panies } \\
\text { Directors of the } \\
\text { postal service } \\
\text { Fraudulent bank- } \\
\text { ers } \\
\text { The king } \\
\text { Politicians }\end{array}$ & People & $\begin{array}{l}\text { Dutch taxpayers } \\
\text { 'Normal' citizens } \\
\text { Parents, pupils } \\
\text { and students } \\
\text { Patients } \\
\text { Employees } \\
\text { Hard-working } \\
\text { business owners } \\
\text { All of us }\end{array}$ \\
\hline $\begin{array}{l}\text { Economic Nati- } \\
\text { vism }\end{array}$ & Foreign & $\begin{array}{l}\text { Illegal Immigrants } \\
\text { Labour Immi- } \\
\text { grants } \\
\text { Moroccan Thugs } \\
\text { Foreigners } \\
\text { Bulgarians } \\
\text { Poles } \\
\text { Romanians } \\
\text { Turks } \\
\text { Muslims }\end{array}$ & Native & $\begin{array}{l}\text { Hardworking } \\
\text { Dutch people } \\
\text { Dutch taxpayers } \\
\text { Dutch citizens } \\
\text { Dutch students } \\
\text { Dutch employees }\end{array}$ \\
\hline $\begin{array}{l}\text { Economic } \\
\text { Authoritarianism }\end{array}$ & Undeserving & $\begin{array}{l}\text { Beggars } \\
\text { Welfare fraud- } \\
\text { sters } \\
\text { Welfare recipi- } \\
\text { ents who use vio- } \\
\text { lence against civil } \\
\text { servants } \\
\text { People who can } \\
\text { but refuse to } \\
\text { work } \\
\text { Bullies }\end{array}$ & Deserving & $\begin{array}{l}\text { Seniors } \\
\text { Pensioners } \\
\text { Children } \\
\text { Vulnerable } \\
\text { Seniors } \\
\text { Senior unem- } \\
\text { ployed people } \\
\text { Handicapped } \\
\text { Patients }\end{array}$ \\
\hline
\end{tabular}

right-wing policies, an ordered logistic regression is employed with the left-right position of the policy as the dependent variable and the group referents as the independent variable. For the groups related to populism referents, the variables are interacted with the sector, which the policy referred to, in order to differentiate, for instance public and private sector elites and mass. ${ }^{7}$ The utility of these categories also depends on their use by parties: if, for instance, a majority of the PVV's motions were simply anti-tax or anti-regulation motions that made no reference to the elite, foreigner or the deserving poor, the party's economic policy agenda should be characterized as neo-liberal instead of the party's nativism, authoritarianism or populism. 
Table 4 Percentage of Motions in Different Categories

\begin{tabular}{lcccccccrc}
\hline $\begin{array}{l}\text { Parliamen- } \\
\text { tary Period }\end{array}$ & Left & $\begin{array}{c}\text { Nei- } \\
\text { ther }\end{array}$ & Right & $\begin{array}{r}\text { Bal- } \\
\text { ance }\end{array}$ & $\begin{array}{r}\text { Popu- } \\
\text { list }\end{array}$ & $\begin{array}{r}\text { Nati- Author } \\
\text { vist }\end{array}$ & $\begin{array}{r}\text { At } \\
\text { itarian } \\
\text { one of } \\
\text { those }\end{array}$ & $\mathbf{N}$ \\
\hline $2006-2010$ & $30 \%$ & $25 \%$ & $45 \%$ & +16 & $21 \%$ & $26 \%$ & $15 \%$ & $59 \%$ & 304 \\
$2010-2012$ & $26 \%$ & $36 \%$ & $38 \%$ & +11 & $19 \%$ & $24 \%$ & $16 \%$ & $55 \%$ & 201 \\
$2012-2017$ & $35 \%$ & $30 \%$ & $35 \%$ & -1 & $13 \%$ & $23 \%$ & $21 \%$ & $52 \%$ & 468 \\
All motions & $32 \%$ & $30 \%$ & $39 \%$ & +7 & $17 \%$ & $24 \%$ & $18 \%$ & $55 \%$ & 973 \\
\hline
\end{tabular}

Balance: percentage of right-wing motions minus the percentage of left-wing motions; At least one of those: the share of motions that is populist, nativist or authoritarian.

$\mathrm{N}$ : Number of motions.

\section{Results}

The core question of this article is whether the PVV's motions were clearly leftwing, right-wing or mixed and what could help to understand a mix. The first question is what the balance between left- and right-wing policies is. Table 4 shows an overview of the number of motions the party proposed in different categories. When looking at the left-right orientation of the motions, one can see that indeed the Freedom Party has a mixed profile: $39 \%$ of motions were economic right-wing and $32 \%$ economic left-wing. The remaining motions would, for instance, mix left-wing and right-wing proposals or were concerned with valence goals such as fighting fraud. The party quite clearly mixes left-wing and rightwing positions; neither left nor right has a majority when it comes to all proposals. The party cannot be consistently characterized as left- or right-wing. Therefore, one would have to reject the left- and right-wing expectation in favour of the mixed expectation.

A majority of motions can be characterized as economic populist, authoritarian or nativist. A quarter of the motions are economic nativist. Nine out of ten of those mention a foreign group (which should be excluded), and a third a national group (which should benefit). This category includes welfare chauvinist motions that seek to exclude migrant groups from accessing the welfare state. Yet the economic nativist policies of the PVV go beyond 'welfare chauvinism': only a quarter of all motions in the nativist category explicitly seek to block non-native groups from access to welfare state benefits, such as social services, housing, healthcare and education. A sixth of nativist motions propose to limit access to the labour market for foreigners. Other economic nativist motions, for instance, focus on foreign states: they propose to cut development aid, oppose bailout plans during the sovereign debt crisis, limit trade or propose to cut funding for the Caribbean islands that form part of the Kingdom of the Netherlands. ${ }^{8}$ Economic nativism is thus a lot broader than simply welfare chauvinism: it is the idea that the economic activity of the government should benefit only native Dutch people and not others. 
Economic authoritarianism also plays: Almost one in five motions fit in this category. Three-fifths of these mention a deserving group that should benefit. Two-fifths of these mention a non-deserving group that should not benefit. Most of these motions focus on healthcare. ${ }^{9}$ Finally, a sixth of all PVV economic motions are economic populist: $98 \%$ mention an elite group that should be made worse off; $37 \%$ mention some 'people' group that should be made better off. Most motions with this frame deal with healthcare (where healthcare management is the focus) or the business sector (most of which focus on the failing bank management after the financial crisis). The PVV is more consistently economically populist, authoritarian and nativist than it is economically left- or right-wing. ${ }^{10}$

Table 3 also gives some indication of the change over time. It shows that the PVV is ideologically quite stable: the share of motions that can be characterized as populist, nativist or authoritarian is always more than $50 \%$. Economic nativist motions make up the largest category. In terms of left and right one can see a slight change: the share of left-wing motions increased somewhat, and the share of right-wing motions decreased over time. All in all, the balance shifts from slightly to the right to left of the centre.

So, the PVV mixes left-wing and right-wing positions, but it is more consistent in its economic authoritarianism, nativism and populism. Can the latter be used to understand the former? Table 5 provides two ordered logistic regressions that can help to elucidate this: they predict the left-right position of a motion by its referents. The first does not include an interaction between sectors and the populist referents, and the second does. First, where it concerns economic nativism: the non-native expectation held that motions that mentioned non-native groups were more likely to be right-wing. This is indeed the case: there is a clear negative effect of mentioning these groups on the right-to-left characterization of motions. So the PVV seeks to reduce government action that would benefit nonnatives. Such an effect is absent for motions that explicitly mention native groups.

Second, the expectations concerning elite groups were more complex: the idea was that radical right-wing populist parties would be right-wing where it concerned public sector elites (public sector elite expectation), but left-wing where it concerned private sector elites (private sector elite expectation). Model 1 shows that the PVV is more left-wing on proposals that mention elite groups. Model 2 shows that adding an interaction leads to significant results. As these are all dummies we can interpret the results quite easily. A motion that mentions elite groups and concerns the public sector is clearly right-wing. ${ }^{11}$ A motion that mentions elite groups in the context of the private sector is clearly left-wing. ${ }^{12}$ This confirms the expectation that whether the PVV's anti-elitism is left or right depends on the sector. When economic populism is applied to the private sector the PVV predominantly makes left-wing proposals: they seek to regulate irresponsible businesses, such as the banking sector after the financial crisis. When economic populism is applied to public sector elites, the PVV proposes cuts in spending or bureaucracy. This pattern is absent for the motions that mention mass groups. These are always right-wing, whether they are in the public sector ${ }^{13}$ or in the private sector. ${ }^{14}$ 
Table 5 Ordered Logistic Regression of Left-Right Position and Referents

\begin{tabular}{|c|c|c|c|}
\hline Variable & & Model I & Model 2 \\
\hline Foreign & & $\begin{array}{r}-0.45 * * * \\
(0.15)\end{array}$ & $\begin{array}{r}-0.56 * * * * \\
(0.16)\end{array}$ \\
\hline Native & & $\begin{array}{l}-0.13 \\
(0.22)\end{array}$ & $\begin{array}{l}-0.19 \\
(0.22)\end{array}$ \\
\hline Elite & & $\begin{array}{r}0.40 * * * * \\
(0.20)\end{array}$ & $\begin{array}{r}2.52 * * * * \\
(0.53)\end{array}$ \\
\hline Mass & & $\begin{array}{l}-0.08 \\
(0.16)\end{array}$ & $\begin{array}{r}-1.08^{* *} \\
(0.39)\end{array}$ \\
\hline Sector $=$ Public & & - & $\begin{array}{r}-0.80 * * * \\
(0.15)\end{array}$ \\
\hline Elite $\times$ Sector $=$ Public & & - & $\begin{array}{r}-2.80 * * * \\
(0.23)\end{array}$ \\
\hline Mass $\times$ Sector $=$ Public & & - & $\begin{array}{r}1.24 * * * \\
(0.43)\end{array}$ \\
\hline Undeserving & & $\begin{array}{r}-0.98 * * * \\
(0.25)\end{array}$ & $\begin{array}{r}-1.26 * * * * \\
(0.26)\end{array}$ \\
\hline Deserving & & $\begin{array}{r}1.95 * * * \\
(0.23)\end{array}$ & $\begin{array}{r}1.79 * * * \\
(0.23)\end{array}$ \\
\hline \multirow[t]{2}{*}{ Intercepts: } & $-1 \mid 0$ & $\begin{array}{r}-0.46 \\
(0.09)\end{array}$ & $\begin{array}{l}-0.03 \\
(0.12)\end{array}$ \\
\hline & $0 \mid 1$ & $\begin{array}{r}0.91 \\
(0.10)\end{array}$ & $\begin{array}{r}1.39 \\
(0.13)\end{array}$ \\
\hline Residual Deviance & & 1984 & 1938 \\
\hline AIC & & 2000 & 1960 \\
\hline $\mathrm{N}$ & & 973 & 973 \\
\hline
\end{tabular}

Finally, we can look at the relationship between referring to the deserving or undeserving groups and left-right policy positions. The deserving poor expectation held that when deserving groups are mentioned, the PVV would put forward left-wing proposals; and where, in contrast, undeserving groups are mentioned it would present right-wing proposals. Both models 1 and 2 show that motions that mention undeserving groups (fraudsters, junkies, bullies) are right-wing: these proposals seek to cut services to undeserving groups. Motions that mention deserving groups (pensioners, handicapped) are left-wing: they are aimed at increasing services for these deserving groups. The mix of left- and right-wing policies here is not due to inconsistency or blurring but actually a reflection of consistent economic authoritarianism that differentiates between deserving poor groups that should be supported ('left-wing') and undeserving poor groups that should not be supported ('right-wing').

These results show that economic authoritarianism, economic nativism and economic populism can be used to understand why the PVV mixes left- and rightwing policies. Because of its economic authoritarianism, the party can combine 
left-wing and right-wing positions on economic issues by distinguishing between the deserving poor, whose hardship is due to circumstances beyond their control and who should be supported, and the undeserving poor, whose poverty is due to their own moral failing and who should not be supported. Economic nativist motions added to the party's right-wing slant as they sought to limit benefits for foreign groups. Economic populist motions that concerned the private sector had a left-wing orientation, as they sought to penalize elite groups.

\section{Conclusion}

How should one characterize the economic agenda of radical right-wing populists? From the perspective of De Lange (2007), the party's economic agenda, which balances left and right policies, may be characterized as centrist, while Rovny (2013) would call its centrism strategic blurring. This article showed that one can also understand the PVV's economic agenda from the perspective of the constituent elements of the ideology of the populist radical right-wing: authoritarianism, populism and nativism. Following Ennser-Jedenastik (2016), this study showed that these inform their economic agenda more consistently than the terms 'left' and 'right' do. One can roughly summarize the radical right-wing populist economic agenda as follows. It desires government action in the economy oriented towards the needs of deserving poor groups, such as seniors, and not towards bureaucrats ('the elite'), immigrants ('the other') and lazy people who are able to work but refuse to do so ('the undeserving poor').

Moreover, this study showed how the approach of Ennser-Jedenastik (2016) and the conventional left-right approach can be reconciled. The mixing and matching of left- and right-wing perspectives by the PVV is the expression of different elements that form a coherent whole: the PVV wants to increase pensions and healthcare provisions for seniors and decrease bonuses for managers of failing banks (left-wing) but opposes the provision of welfare state benefits for immigrants or fraudsters or foreign bailouts that it believes do not benefit the national economy (right-wing). Economic populism, economic authoritarianism and economic nativism are worthwhile to understand the economic policies of radical right-wing populist parties.

This article extends the work of Ennser-Jedenastik (2016) by showing that populism, nativism and authoritarianism were relevant not only for welfare state policies but also for other economic policies of radical right-wing populist parties. For instance, the PVV is welfare chauvinist, but its economic nativism goes beyond that: they also oppose labour migration and financial transfers to foreign countries.

This study showed that at least in regard to the Dutch PVV, approaching economic issues from a multidimensional perspective was useful. The party cannot simply be characterized as left or right. If the PVV's economic policy was informed by its centrism, its closest allies would be the ChristianUnion to its left and the Democrats 66 to its right. However, if one would see that the PVV's apparent centrism is the result of the fact that it mixes left- and right-wing policies on 
the basis of its authoritarianism, populism and nativism, more likely allies would be the Liberal Party when the Freedom Party seeks cuts to spending for immigrants, undeserving poor and bureaucrats and the Socialist Party when the PVV protects the deserving poor and attacks corporate elites.

So what do these results mean beyond the border of the Dutch case? The Freedom Party was a likely case to find these patterns, so no far-reaching conclusions can be drawn from it. Still one may expect that the centrism of other radical right-wing populist parties may be a result of these parties pursuing nativist, authoritarian and populist economic policies. The Flemish Interest, the Danish People's Party, the Front National, the True Finns and Sweden Democrats are likely cases to have economic policy platforms similar to the PVV and the FPÖ. Some radical right-wing populist parties may veer more clearly to the economic right, such as the Alternative for Germany, UK Independence Party, the Norwegian Progress Party and the Swiss People's Party. The majority of the proposals of these three parties may simply be proposals to cut taxes and regulations without references to nativism or populism. If their populism or nativism would express itself in their economic policies, it would only be to support their right-wing agenda by focusing on government elites or welfare state access for immigrants. Future research may want to determine the extent to which authoritarianism, populism and nativism are reflected in the economic policies of other radical right-wing populist parties and the extent to which this party family may stand more united on the economic implications of their shared ideology than on the left-right dimension.

\section{Notes}

1 The question used was: 'Some people think that the differences in incomes in our country should be increased. Others think that they should be decreased. How would you place the PVV on a line from 1 to 7, where 1 means differences in income should be increased and 7 means that differences in income should be decreased?' By comparison, $71 \%$ of voters put the Labour Party on the pro-redistribution side and $62 \%$ the Liberal Party on the anti-redistribution side. It is not that voters are completely oblivious to the policies of the PVV: $80 \%$ of voters identified the party as anti-immigration in a similar question.

2 It is an unanswered question whether economic authoritarianism and welfare chauvinism are separate. Both at the political and at the electoral level these notions appear to be linked: in studies of deservingness, citizens tend to consider immigrants to be less deserving than natives (Hjorth, 2016; Van Oorschot, 2006). At the same time, deservingness is also employed in political debates about the economic implications of immigration (Keskinen, Norocel \& Jørgensen, 2016). Norocel (2016, p. 3) and Schumacher and Van Kersbergen (2016, p. 3) equate the foreign 'Other' with the undeserving poor. They therefore contrast the category of 'undeserving others' with the 'deserving natives'.

3 Here parties have to write clear policy positions if they propose a motion. Compared with some measures that look at election manifestos (Pellikaan et al., 2016), this 
measure does not indicate lower scores if parties do not speak out on issues; rather it looks only at the actual policies parties commit themselves too.

4 Formally, MPs need the support of at least four other MPs to propose motions, but this rule is not enforced (Bovend'Eert \& Kummeling, 2010, p. 343).

5 In the period that Wilders was an independent MP, he proposed only two motions that touch on economic issues. These are disregarded.

6 Although many of these motions concerned economic issues in this sense that the parties favoured or opposed defence, justice and transport spending. These issues are disregarded because they tend to defy a left-right logic: here left-wing parties tend to propose to cut public spending and right-wing parties ask for more spending. By excluding these issues the likelihood of finding more consistent right-wing positioning for the PVV is increased, something that goes against the mixed expectation.

7 Public sector encompasses the budget, culture, development aid, education, the EU, government operations, healthcare, housing, civic integration, pensions, social security and youth care. The private sector concerns communication, energy, enterprise, labour and taxation.

8 In contrast to conservatives of earlier eras, the Freedom Party does not see the Dutch Antilles as part of the fatherland. As the PVV 2012 manifesto put it succinctly: '[i]f it is up to the PVV, the Dutch Antilles would become a foreign country as soon as possible.'

9 One additional question that comes up is to what extent economic nativism and economic authoritarianism, which are often equated in the literature, are actually empirically distinct (Mudde, 2007; Norocel, 2016; Schumacher \& Van Kersbergen, 2016). When one strictly looks at the coding, the overlap is small: only on a limited number of occasions (12 motions) is the undeserving group equated with a foreign group. So empirically these two are different. A the same time, there are differences between the recipients of the kind of social security schemes that the PVV seeks to support (such as the government-ensured minimum pension ('AOW')) and those that it seeks to weaken (such as the welfare scheme 'bijstand' that every legal resident without the means to survive in the Netherlands can call on) under the banner of its economic authoritarianism: according to the Central Bureau of Statistics (2015), 3\% of people with a Dutch passport rely on welfare compared with $11 \%$ of non-Dutch people who live in the Netherlands; in contrast, $20 \%$ of residents of the Netherlands whose parents were both born in the Netherlands receive a government-insured pension, compared with only $11 \%$ of residents of the Netherlands one of whose parents is not born in the Netherlands (CBS, 2016). Boosting pension spending and limiting welfare spending can be understood from an economic nativist perspective, but that goes beyond the approach of this article. This is an example of indirect welfare chauvinism (Careja, Elmelund-Præstekær, Klitgaard \& Larsen, 2016).

10 Three motions could be characterized as anti-nativist (two motions called to defund Dutch development organizations for their opposition to the Israeli government, and one sought to attract more foreign investors to the Netherlands); four motions could be characterized as anti-populist (these sought, for instance, to maintain distinction between research universities and universities of applied science); and a single motion as anti-authoritarian. 
11 The total effect (of referring to elite groups, to the public sector and their interaction) is -1.08 and therefore greater than the -0.03 threshold.

12 The coefficient is 2.52 and significantly higher than 1.39 .

13 The total effect (of referring to mass groups, to the public sector and their interaction) is -0.64 , which is significantly beyond the -0.03 threshold.

14 The coefficient $(-1.08)$ is significantly lower than -0.03 .

\section{References}

Afonso, A. (2015). Choosing whom to betray: Populist right-wing parties, welfare state reforms and the trade-off between office and votes. European Political Science Review, 7, 271-292.

Afonso, A., \& Papadopolous, Y. (2015). How the populist radical right transformed Swiss welfare politics. From compromises to polarization. Swiss Political Science Review, 21, 617-635.

Akkerman, T., De Lange, S. L. \& Rooduijn, M. (Eds.). (2016). Radical right-wing populist Parties in Western Europe. London: Routledge.

Andersen, J. G. \& Bjørklund, T. (1990). Structural changes and new cleavages: The Progress Parties in Denmark and Norway. Acta Sociologica, 33(3), 195-217.

Bakker, R., et al. (2014). 2014 Chapel Hill Expert Survey. Chapel Hill: University of North Carolina.

Bang Petersen, M., Sloothuus, R., Stubager, R. \& Togeby, R. (2010). Deservingness versus values in public opinion on welfare: The automaticity of the deservingness heuristic. European Journal of Political Research, 50, 24-52.

Betz, H.-G. (1994). Radical right-wing populism in Western Europe. Basingstoke: Macmillan.

Bovend'Eert, P. P. T. \& Kummeling, H. R. B. M. (2010). Het Nederlandse parlement. Deventer: Kluwer.

Careja, R., Elmelund-Præstekær, C., Klitgaard, M. B. \& Larsen, E. G. (2016). Direct and indirect welfare chauvinism as party strategies: An analysis of the Danish People's Party. Scandinavian Political Studies, 39(4), 435-457.

CBS. (2015). Zeven van de tien Somaliërs in de bijstand. Retrieved July 25, 2016, from https://www.cbs.nl/nl-nl/nieuws/2015/31/zeven-van-de-tien-somaliers-in-debijstand

CBS. (2016). AOW uitkeringen. Retrieved July 25, 2016, from http://statline.cbs.nl/ StatWeb/publication/?VW=T\&DM=SLNL\&PA=71330ned\&D1=a\&D4=a\&D5=0-2\& D6=a\&D7=1\&HD=090903-0133

De Koster, W., Achterberg, P. \& van der Waal, J. (2012). The new right and the welfare state: The electoral relevance of welfare chauvinism and welfare populism in the Netherlands. International Political Science Review, 34, 3-20.

De Lange, S.L. (2007). A new winning formula? The programmatic appeal of the radical right. Party Politics, 13, 411-435.

De Lange, S. L., \& Art, D. (2011). Fortuyn versus Wilders: An agency-based approach to radical right party building. West European Politics, 34(6), 1229-1249.

Derks, A. (2006). Populism and the ambivalence of egalitarianism. How do the underprivileged reconcile a right wing party preference with their socio-economic attitudes? World Political Science Review, 2, 528-553.

Eger, M. A. \& Valdez, S. (2015). Neo-nationalism in Western Europe. European Sociological Review, 31, 115-130. 
Ennser-Jedenastik, L. (2016). A welfare state for whom? A group-based account of the Austrian Freedom Party's social policy profile. Swiss Political Science Review, 22, 409-427.

Handler, J. F. (2004). Social citizenship and workfare in the United States and Western Europe. The Paradox of Inclusion. Cambridge: Cambridge University Press.

Harteveld, E. (2016). Winning the 'losers' but losing the 'winners'. The electoral consequences of the radical right moving to the economic left. Electoral Studies, 44 , 225-234.

Hjorth, F. (2016). Who benefits? Welfare chauvinism and national stereotypes. European Union Politics, 17, 3-24.

Ignazi, P. (1992). The silent counter-revolution. European Journal of Political Research, 22, 3-34.

Ivaldi, G. (2015). Towards the median economic crisis voter? The new leftist economic agenda of the Front National in France. French Politics, 13, 346-369.

Jagers, J. \& Walgrave, S. (2007). Populism as a political communication style: An empirical study of political parties' discourses in Belgium. European Journal of Political Research, 46, 319-345.

Jørgensen, M. B. \& Thomsen, T. L. (2016). Deservingness in the Danish context: Welfare chauvinism in times of crisis. Critical Social Policy, 36, 1-22.

Keskinen, S. (2016). From welfare nationalism to welfare chauvinism: Economic rhetoric, the welfare state and changing asylum policies in Finland. Critical Social Policy, 36, 1-19.

Keskinen, S., Norocel, O. C., \& Jørgensen, M. B. (2016). The politics and policies of welfare chauvinism under the economic crisis. Critical Social Policy, 36, 1-9.

Kitschelt, H. \& McGann, A. J. (1995). The radical right in Western Europe. Ann Arbor, MI: University of Michigan Press.

Kriesi, H.-P., Grande, E., Dolezal, M., Helbing, M., Höglinger, D., Hutter, S. \& Wüest, B. (2012). Political conflict in Western Europe. Cambridge: Cambridge University Press.

Kriesi, H.-P., Grande, E., Lachat, R., Dolezal, M., Bornschier, S. \& Frey, T. (2008). West European politics in the age of globalization. Cambridge: Cambridge University Press.

Lefkofridi, Z., \& Michel, E. (2017). The electoral politics of solidarity. The welfare agendas of radical right parties. In K. Banting \& W. Kymlicka (Eds.), The strains of commitment: The political source of solidarity in diverse societies. Oxford: Oxford University Press.

Louwerse, T., \& Otjes, S. (2016). Personalised parliamentary behaviour without electoral incentives: the case of the Netherlands. West European Politics, 39(4), 778-799.

Louwerse, T., Otjes, S. \& van Vonno, C. (2017). The Dutch parliamentary behaviour dataset. Acta Politica. 53(1), 149-166.

March, L. (2011). Radical left parties in Europe . Routledge: Oxford.

Minkenberg, M. (2000). The renewal of the radical right: Between modernity and antimodernity. Government and Opposition, 35(2), 170-188.

Mudde, C. (2007). Populist radical right parties in Europe. Cambridge: Cambridge University Press.

Mudde, C. (2013). Three decades of populist radical right parties in Western Europe: So what? European Journal of Political Research, 52(1), 1-19.

Mudde, C. (2016). The study of populist radical right parties: Towards a fourth wave. CRex Working paper series, \#1, University of Oslo.

Norocel, O. C. (2016). Populist radical right protectors of the folkhem: Welfare chauvinism in Sweden. Critical Social Policy, 36, 1-20.

Otjes, S., \& Louwerse, T. (2015). Populists in parliament: Comparing left-wing and rightwing populism in the Netherlands. Political Studies, 63(1), 60-79. 
Pauwels, T. (2010). Explaining the success of neo-liberal populist parties: The Case of Lijst Dedecker in Belgium. Political Studies, 58, 1009-1029.

Pellikaan, H., de Lange, S. L. \& van der Meer, T. W. G. (2016). The centre does not hold: Coalition politics and party system change in the Netherlands, 2002-12. Government and Opposition. Published online ahead of print.

PVV. (2012). Hún Brussel, óns Nederland. Election manifesto PVV.

Rovny, J. (2013). Where do radical right parties stand? Position blurring in multidimensional competition. European Political Science Review, 5, 1-26.

Schumacher, G., \& Van Kersbergen, K. (2016). Do mainstream parties adapt to the welfare chauvinism of populist parties. Party Politics, 22, 300-312.

Stanley, B. (2008). The thin ideology of populism. Journal of Political Ideologies, 13, 95-110.

Van der Brug, W., \& Van Spanje, J. (2009). Immigration, Europe and the 'new' cultural cleavage. European Journal of Political Research, 48, 309-334.

Van der Kolk, H., Tillie, J. N., Van Erkel, P., \& van der Velden, M. (2012). Dutch parliamentary election study 2012. The Hague: CBS.

Van der Waal, J., \& de Koster, W. (2017). Populism and support for protectionism: The relevance of opposition to trade openness for leftist and rightist populist voting in The Netherlands. Political Studies, published online ahead of print.

Van Oorschot, W. (2006). Making the difference in social Europe: Deservingness perceptions among citizens of European welfare states. Journal of European Social Policy, 16, 23-42.

Visscher, G. (1994). Parlementaire invloed op wetgeving. Een inventarisatie van de invloed van de beide Kamers der Staten-Generaal op de wetgevende activiteiten van de kabinetten Marijnen tot en Met Lubbers I. Den Haag: SDU.

Vossen, K. (2013). Rondom Wilders. Portret van de PVV. Amsterdam: Boom.

Wilders, G. \& Oplaat, G. J. (2004). Tienpuntenplan.

Will, J. (1993). The dimensions of poverty: Public perceptions of the deserving poor. Social Science Research, 22, 312-332. 